\title{
A Multi-Methodological Analysis of a Non-Clinical Healthcare Executive and Servant Leader: Attributes and Behaviour's and their Associations with Reporting Relationships and Business Structures \\ Dr. Harold Ray Griffin* \\ Professor, Health Services Management, \\ Brazosport College \\ Email: harold.griffin@brazosport.edu
}

USA

Ms. Dana Foster

Adjunct Professor

Business Administration and Computer Technology

Brazosport College

USA

\section{ABSTRACT}

A multi-methodological approach was used to examine the personal and professional life of a well-respected, nonclinical, healthcare executive for purposes of determining if "Don" was a servant leader and, if so, uncover the antecedents contributing to his leadership style. The results provided the backdrop for examining linkages between servant leadership, reporting relationships, and business structures. Content analysis and Spears' 10 constructs of servant leaders were used as a priori themes to affirm that Don is a servant leader. Nonparametric testing revealed moderate to strong associations between the reporting relationships of the respondents $\left(x^{1}\right)$ and the types of business structures $\left(x^{2}\right)$ where the respondents and our servant leader forged their initial relationship and the perceived behaviors and attributes of Don (y). We discovered that relationships, spiritual centeredness, and desire for career advancement served as antecedents in shaping Don's leadership style. Implications for practice and future research are also addressed.

\section{Keyword: servant leadership, antecedents of servant leaders, healthcare executives}

\section{Introduction}

The healthcare industry like many other sectors within the economy is in the midst of a leadership crisis. More specifically, when faced with moral dilemmas, leaders are choosing to put their interests above that of other stakeholders (Graham, 1991; Laub, 2003; Russell, 2001; Griffin, 2004). As a result, there has been building interest in leadership values and morality in the eyes of the public. There is one contemporary leadership theory, servant leadership, which promotes positive values and morality while emphasizing individualized consideration and appreciation of followers (Stone et al.,2004). Servant leaders put the needs of others above their selfinterest, which is perceived by some as a hallmark characteristic of good leadership (Greenleaf, 1977). In light of this leadership challenge, servant leadership is gaining widespread popularity and is being touted as a complete departure from the selfish leadership styles that are frequently highlighted in the public (Bekker, 2010; Greenleaf, 1977); however, there is a need for more empirical evidence to support the theory (Eva et al., 2019). Peterson et al. (2012), noted that there is a need to further research the attributes associated with servant leaders holding executive roles within the organization. Along these lines, the need to gain a deeper understanding of the antecedents of servant leadership, as a unique form of leadership, responds to the call of scholars (Avolio,2007; DeRue et al., 2011) for research that conceptually and empirically distinguishes the antecedents and consequences of various forms of leadership (Peterson et al., 2012).

Current studies into servant leadership have generally been focused on three areas: conceptual, measurement, and model development (van Dierendonck \& Patterson, 2010; Eva et al, 2019). In health care, there has been a lack of published studies supporting the presence and relative value of servant leadership. This research has been largely limited to clinical disciplines and largely ignores the non-clinical executives. More specifically, missing from the research is an examination of specific attributes and behaviors associated with healthcare executives who are outwardly perceived to be servant leaders through the eyes of those for whom they have a reporting relationship and in differing organizational structures. Also, the current body of literature doesn't address the frequency in which servant leaders demonstrate certain attributes and behaviors. We believe this point is particularly important since organizational needs can drive leadership selection decisions. While servant leaders may share a common set of attributes 


\section{(C) Center for Promoting Education and Research (CPER) USA}

WWW.cpernet.org

and outwardly display a unified set of behaviors, it is unlikely that these behaviors and attributes will be equally represented in every servant leader. It is more likely that the specific attributes and behaviors needed from servant leaders may vary based on reporting relationships and the types of business structures. Understanding this dynamic will allow healthcare organizations to optimally leverage their servant leaders to effectively address the needs of the organization and those for whom they interface.

\section{Purpose of the Study}

The purpose of this study was to begin to develop a deeper and more pragmatic understanding of the attributes and behaviors associated with nonclinical servant leaders holding executive healthcare positions. This was accomplished by theming respondent observed attributes and behaviors into the appropriate constructs of servant leadership as postulated by Spears. Also, we took into consideration that there may be associations between the type of business relationships between the leader and those working within the organization and the types of business structures where these relationships were forged to that of the constructs.

The objectives of this study were met by providing qualitative comparisons and drawing parallels between Spears' constructs of servant leadership and the professional life of Don. He was chosen to be the focus of this study given his prominence within the healthcare community and the fact that he possessed more than 65 years of combined military and civilian healthcare administration experience and had held some senior executive positions throughout his career. We qualitatively examined Don's personal and professional life to inductively cull out the antecedents of servant leadership. In addition to the qualitative analysis, the objectives were met by performing relevant nonparametric analysis of the nature and strength of associations between types of business relationships and structures to that of Don's alignment with Spears' constructs.

\section{Significance of the Study}

This study will begin to address existing gaps in the current body of knowledge as they pertain to the presence and relevance of servant leadership in health care. While a limited number of studies have been directed to the healthcare industry, the majority of these published works have been narrowly focused on aspects of servant leadership as applied to the clinical disciplines. Since it is well established that the corporate culture is largely influenced by the leadership style of its' management team, it stands to reason that gaining a more precise understanding of the behaviors and attributes of a prominent servant leader is a logical first step in better appreciating the value these individuals bring to their organizations.

There has been a concerted effort by servant leadership scholars to create conceptual frameworks, develop new models, and create measures (van Dierendonck \&
Patterson, 2010), but much of this is not based on the observed behaviors and attributes of servant leaders, but rather loosely built upon the work of others (van Dierendonck, 2011). The findings from this study may serve as a basis for the development of future quantitative instrument development whereby the measured items will originate from the observed attributes and behaviors of Don. Also, understanding the associations between the types of business relationships and settings where these relationships are cultivated will provide a context for future scale development. Finally, by understanding how the reporting relationships and business structures influence one's perception of servant leaders' behaviors and attributes, organizations can better predict which setting and under what circumstances these leaders will add the greatest value to their organizations. It is hoped that this study will serve as a springboard for future empirical studies that aspire to develop a more comprehensive understanding of the inherent complexities associated with servant leadership and determine how best this form of leadership can serve the healthcare community and its internal and external stakeholders.

\section{Research Questions and Hypotheses}

RQ1: Does Don outwardly demonstrate the attributes and behaviors associated with Spears' 10 constructs of servant leadership as described by the study respondents?

RQ2: Operating under the assumption that Don is determined to be a servant leader, what are the antecedents of servant leadership reflected in his personal and professional life?

RQ3: Is there an association between the types of business relationships and the settings in which these relationships were formed and the servant leadership constructs associated with Don?

Ho1: There is no statistical association between the reporting relationships with Don and their collective perceptions of his attributes and behaviors as reflected in Spears' servant leadership constructs.

Ha1: There is a statistical association between the reporting relationships with Don and their collective perceptions of his attributes and behaviors as reflected in Spears' servant leadership constructs.

Ho2: There is no statistical association between the types of business structures where the respondents originally formed their relationship with Don and their perceptions of his attributes and behaviors as reflected in Spears' servant leadership constructs.

Ha2: There is a statistical association between the types of business structures where the respondents originally formed their relationships with Don and their perceptions of his attributes and behaviors as reflected in Spears' servant leadership constructs. 


\section{CCenter for Promoting Education and Research (CPER) USA}

WWW.cpernet.org

\section{Materials and Methodology}

This study utilized a multi-methodological approach. To begin to develop a deeper understanding and appreciation for the actual behaviors and attributes inherent in servant leaders holding high-level, nonclinical positions within healthcare organizations, we felt strongly that there should be a singular focus on one healthcare leader. After careful consideration, it was decided to make Don the focus of this study based on his lengthy tenure in the healthcare administration discipline; the numerous senior-level positions he's held in both the military and civilian healthcare sectors; his prominent status within the healthcare community; his many contributions to the discipline; and his reputation for being a leader who outwardly appears to embody many of the attributes and behaviors commonly associated with servant leaders. While his personal and professional journal may differ from that of other nonclinical, senior, healthcare leaders, we believe his behaviors and attributes are not dissimilar from other servant leaders holding similar positions.

A case study design was used to determine whether or not he did, in fact, demonstrate the behaviour's and attributes of a servant leader. This research design is considered useful when the aim is not only to determine if a person displays certain characteristics and behaviour's, but when it is the intention to solicit the perceptions of those who interact with him or her in the context of particular settings or in various professional capacities (Biddix, n.d.). For purposes of this study, we conducted a series of semi-structured, telephonic interviews with health industry professionals for whom Don had a business relationship in different types of business structures. The questions were designed to elicit the respondents' impressions and opinions about Don's person, attributes, behaviour's, leadership style, and nature of his relationships with others. The respondents were also afforded the opportunity to discuss other topics not addressed in the interview questions, so long as they were relevant to the intent of the study. The interview questions for Don were more selfreflective in nature, but intended to glean insight into the antecedents associated with his leadership attributes and behaviour's; ascertain his perceived strengths and weaknesses; how he leads through challenging times; and what he believes makes him a particularly effective leader. As with the respondents, he was also given the opportunity to share thoughts not previously covered in his responses to previous interview questions. These interviews were transcribed (verbatim) and using software aided techniques through Microsoft's text formatting features, find-and-replace command, and macro programming language we analytically coded the qualitative data, using a priori constructs, to enhance the reliability of the study. In addition, we recorded our reflections, thoughts, and observations on "contact summary sheets"; used the "content analysis coding sheets" to actually record words, phrases, and passages that aligned under the $a$ priori themes (i.e., awareness, building sense of community, commitment to the growth of people, conceptualization, empathy, healing, foresight, listening, persuasion, stewardship), and then a "content analysis coding sheet" was dedicated to recording the frequency of coded occurrences per construct. In addition to the previously mentioned measures to capture relevant qualitative date, we utilized a number of structured approaches to ensure the credibility and dependability of the findings.

With regard to establishing dependability in the study, multiple researchers were used to independently code the transcript data into a priori themes using established protocols developed by the principals. The study underwent purposeful triangulation through the use multiple researchers, methods, and sources with the aim of ensuring the highest levels of integrity in the data collection, analysis, and interpretation processes.

In order to maximize the accuracy of the interpretations and support the credibility and confirmability of the results, the researchers performed inter-rater reliability, intra-rater reliability, and member checks. With respect to the intra-rater reliability, the percent of agreement was $86.57 \%$. The inter-rater reliability results were $82.91 \%$ and $90.03 \%$ for the first and second independent researcher respectively. Respondents were asked to review their interview transcripts and coding results, and then document their agreement or disagreement with the findings. Nine (9) or $60 \%$ of the study informants provided member check feedback to the researcher, which resulted in a percentage of agreement of $100 \%$. The qualitative comments received by the study participants were overwhelmingly affirming. Here is an example of a typical response:

I have reviewed both documents [transcript and results]. I believe you have captured my intent. Clearly, you heard with clarity discerning what I want to convey. After reading my comments, I am amazed at how you were able to glean that information out of my blathering.

The study also employed an ex post facto research design, since this approach was particularly useful given that we had no intention of manipulating the independent variables: reporting relationships, $\mathrm{x}_{1}$, and business structures, $\mathrm{x}_{2}$. More specifically, the study examined statistical associations and the accompanying strengths of these relationships between the independent variables and the behaviors and attributes described by the respondents, which were later themed under the appropriate a priori constructs of servant leadership (y) as originally postulated by Spears (1998). This was accomplished through the performance of Pearson's $\chi^{2}$ test of independence and Cramer's phi $\left(\varphi_{c}\right)$.

\section{Study Participants}

The sample consisted of healthcare industry professions for whom Don had a business relationship, such as superiors, subordinates, peers, and business associates who had 


\section{(C) Center for Promoting Education and Research (CPER) USA}

WwW.cpernet.org

more than a casual industry acquaintance. The network sampling methodology was utilized in such a manner as to gain the widest array of perspectives regarding Don's attributes and behaviors. Of the 54 possible study participants, including Don, 24 failed to meet the inclusion criteria for the study or where missing necessary contact information. Of the 30 suitable candidates who met the criteria for inclusion, 15 (or $50 \%$ ) accepted the offer to join the study while the others opted to decline the invitation. There were 3 females and 12 males in the sample, with a $M \approx 22$ years of cultivating an ongoing professional relationship with Don. The 15 participants $(N=15)$ were purposively assigned to one of two categories that related to the reporting relationship they had with Don those who directly reported to him (i.e., subordinates) and those who did not (i.e., himself, supervisors, peers, business associates). There were eight respondents who reported to Don $(n=8)$ and six who did not $(n=6)$. Furthermore, the respondents were then purposively assigned to one of two categories related to the types of business structure where they subsequently forged a relationship with Don the first being nonprofit, private healthcare organizations (tax exempt organizations that are focused primarily on meeting the healthcare needs of civilian communities) and nonprofit, public healthcare organizations (tax exempt organizations that are focused on primarily meeting the healthcare needs of military service members and dependents). Eight $(n=8)$ of the respondents self-reported establishing a business relationship with Don while they both worked in a nonprofit, private setting, whereas seven $(n=7)$ reported establishing a business relationship when they were employed at a nonprofit, public healthcare organization.

\section{Results}

The qualitative analysis resulted in a total of 269 coded occurrences assigned to an a priori construct of servant leadership. The results are summarized in Table 1 and Figure 1. More precisely, the first column of the table contains the Spears' 10 constructs while the second column provides the qualitatively coded data under each construct and is represented in the form of words, phrases, and passages, and lastly the third column contains the number of coded occurrences associated with each construct and their accompanying percentage set within parentheses. To enhance the reader-friendliness of Table 1, we opted not to repeat those codes that were mentioned more than once; however, the coded occurrences reflected in the last column are accurate and capture the total instances where the codes were recorded by us over the course of the study ( $T_{j}$, total count for $\mathrm{j}$ th row). Figure 1 depicts a Pareto chart where not only are the coded occurrences for each construct prominently presented, but also individual and cumulative percentages. The qualitative results are presented first followed by the quantitative analyses.

\section{Table 1: Qualitative Content Analysis Results}

\begin{tabular}{|c|l|c|}
\hline $\begin{array}{c}\text { Themes } \\
\text { (Spears' Constructs) }\end{array}$ & \multicolumn{1}{c|}{$\begin{array}{c}\text { Coded Data } \\
\text { (words, phrases, and passages) }\end{array}$} & $\begin{array}{c}\text { Coded } \\
\text { Occurrences }\end{array}$ \\
\hline Listening & $\begin{array}{l}\text { ability to listen; great listener; genuinely interested in the opinions of } \\
\text { others; makes one feel that they are the most important person } \\
\text { during a conversation; "open door policy" }\end{array}$ & $37(13.76 \%)$ \\
\hline Empathy & $\begin{array}{l}\text { sees the best in everyone; very sympathetic and compassionate; deep } \\
\text { and abiding concerns for friends and enemies; overestimate the } \\
\text { strengths of others; very patient; sees the best in everyone; may not } \\
\text { push people hard enough; never insults or is ugly to anyone; } \\
\text { struggles to make difficult decisions (e.g., RIF), since it will } \\
\text { negatively impact the staff and their families despite supervisory } \\
\text { directives }\end{array}$ & $21(7.81 \%)$ \\
\hline Healing & $\begin{array}{l}\text { bring people together in times of crisis; shares experiences with } \\
\text { others; reaches out to people who hurt; employees aren't afraid to } \\
\text { show their vulnerabilities; willing to admit his mistakes; uses his } \\
\text { sense of humor to make people feel better; first to reach out to } \\
\text { employees following the death of a family member; not afraid to } \\
\text { reveal his vulnerabilities }\end{array}$ & $12(4.46 \%)$ \\
\hline Awareness & $\begin{array}{l}\text { very high integrity; a really spiritual person; value-driven; honesty; } \\
\text { knows "right from wrong"; do what is right; highly ethical; } \\
\text { trustworthy; self-aware of strengths and weaknesses; shares his } \\
\text { perception of weaknesses and strengths of others; routinely walks } \\
\text { throughout the organization to observe the goings on; surrounded } \\
\text { himself with talented personnel to overcome his shortcomings }\end{array}$ & 29 (10.78\%) \\
\hline getting people to vote in agreement; sharing one's point of view to & $11(4.10 \%)$ \\
\hline
\end{tabular}




\section{(C) Center for Promoting Education and Research (CPER) USA}

\begin{tabular}{|c|c|c|}
\hline Persuasion & $\begin{array}{l}\text { influence behavioral responses; clear about where one stands on an } \\
\text { issue; meeting "half way" to reach consensus; could reprimand you } \\
\text { and you leave his office thanking him; skillful negotiator; never says } \\
\text { "you need to do this"; able to persuade others; "you may disagree } \\
\text { with him, but you'll walk away seeing his point of view; prepares, in } \\
\text { advance, to present his arguments and encourages others to do the } \\
\text { same }\end{array}$ & \\
\hline Conceptualization & $\begin{array}{l}\text { good strategic planner; able to change paradigms; remains "open- } \\
\text { minded"; vision; makes directional decisions and stays the course; } \\
\text { he brings and encourages others to bring ideas to the table }\end{array}$ & $19(7.06 \%)$ \\
\hline Foresight & $\begin{array}{l}\text { anticipates; understands the impact of certain decisions; willingness } \\
\text { to take calculated risks; review the past and present to formulate } \\
\text { decisions regarding the future; "turnaround artist"; helps others see } \\
\text { processes; demonstrates technical knowledge of business in } \\
\text { understanding the impact of things; gives great thought and attention } \\
\text { to details; uses his knowledge and experience to make effective } \\
\text { decisions; he anticipates; makes decisions after having the facts }\end{array}$ & $11(4.10 \%)$ \\
\hline Stewardship & $\begin{array}{l}\text { preserved and strengthens the institution for the benefit of the } \\
\text { community; promotes the industry; succession planning; dedicated } \\
\text { to organization; his commitment to organizational success makes } \\
\text { him well suited to assume interim CEO positions; refuses to transfer } \\
\text { personnel if it would negatively impact the organization; single } \\
\text { minded in terms of mission }\end{array}$ & $17(6.30 \%)$ \\
\hline $\begin{array}{l}\text { Commitment to Growth } \\
\text { of People }\end{array}$ & $\begin{array}{l}\text { mentorship; teacher; helps other succeed in their careers; allows } \\
\text { autonomy and room to grow; encouraged education; instill } \\
\text { confidence; empowering others; passionate about developing talent; } \\
\text { supporter of higher education; encourages membership in } \\
\text { professional organizations (e.g., ACHE); does what it takes to make } \\
\text { people successful; takes people "under his wing"; routinely travels } \\
\text { distances to deliver addresses to new classes of health administrators } \\
\text { with reimbursement }\end{array}$ & $42(15.61 \%)$ \\
\hline Building Community & $\begin{array}{l}\text { modest; "gives credit where credit is due"; builds relationships; } \\
\text { treats all employees with respect; "management by walking around"; } \\
\text { made certain the staff had the resources necessary to do their jobs; } \\
\text { volunteers his time to lead projects and tasks; people rally around } \\
\text { him; has the ability to motivate people; creates a collaborative work } \\
\text { environment; "there is no me, myself, and I"; wants to make certain } \\
\text { that everyone has their time with him; treats everyone like family; } \\
\text { works equally well with young and seniors; shared vision and } \\
\text { mission with staff }\end{array}$ & $70(26.02 \%)$ \\
\hline
\end{tabular}

\section{Antecedents of Servant Leadership}

In an interview that lasted one and half hours, interesting themes emerged which we considered antecedents to servant leadership: family influences, mentorship, spiritual centeredness, and a desire to assume leadership roles of greater responsibility. Each of these themes is a constant influence throughout his formative years (childhood through college), military and civilian healthcare careers, and semi-retirement. He was born into a working-class family, in 1930, during the Great Depression, and in a small town in Pennsylvania, where racial segregation was still common practice. His family remained a constant source to support and encouragement throughout his childhood and into adulthood. His parents instilled in him a strong set of values that would guide him throughout his personal and professional life. Following graduation from college, in 1952, he accepted a commission in https://ijbassnet.com/ the United States Air Force and married his high school sweetheart, Jan. He credits Jan for not only being a "good influence" on him but also helped shape how he influenced others. During the interviews with respondents, it was frequently pointed out that Don treated them like a member of his "family". It is also clear that this sentiment is reciprocated by Don, as he shared numerous examples of the relationships he forged throughout his career and how these relationships have influenced his leadership style.

Don spent a lot of timesharing insights into some of the influential mentors that shaped and guided his personal and professional life. As the family has been an antecedent shaping his leadership style through his formative, career, and into semi-retirement, so have the mentors that took an interest in his success and guided many of his personal and professional decisions. He fondly recalled the adults who served as mentors 


\section{CCenter for Promoting Education and Research (CPER) USA}

WWW.cpernet.org

while he engaged in after-school activities at the local Young Men's Christian Association (YMCA). He commented:

In our town...I was from a small town in Pennsylvania, and in that town, there were not a lot of outside activities, but the YMCA was one of them. That was in the days that the YMCA meant and acted out its motto was about Young Men's Christian Association. There were wonderfully available and forthcoming adult mentors that had an enormous influence on my early years.

During his first semester of college, he didn't perform all that well, finding himself placed on academic probation. $\mathrm{He}$ was a member of the work-study program and was assigned to assist the trainer for the athletic programs. The trainer and his family lived on campus, and soon took an interest in Don's success. Not only did Don provide him guidance and support to succeed in school, but also set him on a path that would eventually lead him to become a licensed physical therapist. $\mathrm{He}$ commented that during the latter portion of his military career he "...experienced continued growth [promotions], continued mentorship, and wonderful examples of leadership to which I was exposed all that time." He specifically recounted a colleague, who possessed more experience in health administration that personally took him "...under his wing..." and helped him realize his potential to be a successful health administrator over and above physical therapy by itself. Don recalled another influential mentor who, in 1952, was a hospital administrator at Randolph Air Force Base at the same time he was stationed there as a physical therapist. He credited this mentor with his practice of getting out of this office and routinely interfacing with staff, physicians, and patients. More specifically he recalled that his mentor would say:

Don, when you go to a new institution, the first thing you do is get a master key, and you open every door in that place. He added, two things come out of that. First off, you're doing it with the people who live in that real area; you're not sneaking around behind them. You're going it with them because you want to learn about their real estate. You'll be astounded that you lean by what you see on the shelves and behind that closed door. You'll be astounded by what that will mean to the people who can say accurately, 'This is the first time anybody ever came and looked in my supply closet'.

The next antecedent is related to spiritual centeredness. Since his youth, involvement in the church has been a constant. This was through his local church affiliation and reinforced in the home and at the local YMCA. Throughout his adult life, Don has always maintained a strong commitment to his spiritual beliefs, which has, in turn, kept him grounded, and served as an antecedent to his leadership style. This point wasn't only referenced during his interview but is reflected in the coded data from the respondents. There are many references to how his spiritual focus has influenced his attributes and behaviors and is perceived to be one of his strengths.
The final antecedent is the motivation for career advancement. The basic premise behind servant leadership is that "true leadership emerges from one whose primary motivation is a deep desire to serve" (Sipe \& Frick, 2009, p. 36). While this statement is true, it is also fair to say that servant leaders aspire to achieve career advancement. This desire for advancement is driven by a need to promote the greater good and not for selfish and self-serving reasons. Greenleaf (2003, p. 33) declared, the servant leader “....is more likely to emerge in practice in those segments of society where the concern is most intensely felt for justice (rather than order), for the performance (rather than the result) of our institutions, and the appropriateness (rather than the result) of power and authority." Don saw advancement as his opportunity to effect necessary changes within healthcare and that by focusing on meeting the needs of the staff he could enhance organizational performance and better serve the clients and community. As a result, Don strategically pursued some career advancement opportunities throughout his career, which eventually led to him being the first general grade officer in the U.S. Air Force's Medical Services Corp, and in a succession of executive promotions culminating in his becoming a Chief Executive Officer in one of the largest health systems in East Texas. The lessons learned in the advancement of his career fueled his commitment to support others on their journey to selfactualization.

\section{Content Analysis}

The Pareto illustrates that $66.2 \%$ of the coded data fell within four constructs: building a sense of community, commitment to the growth of people, listening, and awareness. Upon closer examination of the individual construct percentages by IV and their associated groupings $\left(k_{\mathrm{c}}\right)$, it was discovered that for those who reported directly to Don tended to observe behaviors associated with listening and awareness more frequently than those who didn't report to him (15.34\% and $\approx 13 \%$ as compared to $10 \%$ and $\approx 6 \%$ respectively). Conversely, those who didn't report to Don described a higher frequency of behaviors associated with building a sense of community and stewardship when compared to those respondents who reported to $\operatorname{him}(30 \%$ and $24.3 \%$ as compared to $12.5 \%$ and $\approx 4 \%$ respectively). When considering the respondents' description of Don's behaviors and taking in to account the business setting in which they were affiliated, those in nonprofit, private organizations seemed to emphasize his listening and awareness behaviors more so than those associated with nonprofit, public settings $(16 \%$ and $\approx 14 \%$ as compared to $\approx 11 \%$ and $7 \%$ respectively).

According to Yin (1994), when performing qualitative content analysis, the researcher can legitimize a theme when there is a minimum of 10 coded occurrences associate with that particular theme. In the Pareto, this threshold is graphically represented by the horizontal black line that runs from " $10 "$ on the primary vertical axis to the " 13.0 " on the 
secondary vertical axis (see Figure 1). Based on the content analysis, it appears that Don does, in fact, demonstrate the attributes and behaviors typically associated with servant leaders when applying Spears' constructs as a priori themes. Tests of Independence

We first began the quantitative analysis by looking for statistically significant associations between the reported attributes and behaviors of Don, as themed under Spears' constructs of servant leadership with the nature of the reporting relationships he had with the study respondents and the types of business structures where these relationships first developed. To perform this analysis, we applied the Pearson's $\chi^{2}$ test if independence, $\alpha=.10$ (two-tailed) and $d f=9,(\mathrm{r}-1)(\mathrm{c}-$ 1):
Using the p-value approach, the relationship between these variables was determined to be statistically significant, $\chi^{2}$ $(9, N=322)=26.87, p<.01$. There is an association between the reporting relationships to Don and their collective perceptions of his attributes and behaviors as reflected in Spears' servant leadership constructs. While we established a statistically significant relationship between the variables, there was still a need to ascertain the strength of the association. To make this determination, we used Cramer's phi, $\varphi_{c}$, which is calculated using the formula: $\varphi_{c}=$ $\sqrt{\chi 2 / N(k-1)}$. The result revealed a moderately strong relationship between the variables $\left(\varphi_{c}=.28892\right)$.

$$
\chi 2=\sum_{i, j} \frac{(f i j-e i j)}{e i j}
$$

\section{Figure 1: Pareto chart of coded occurrences by construct}

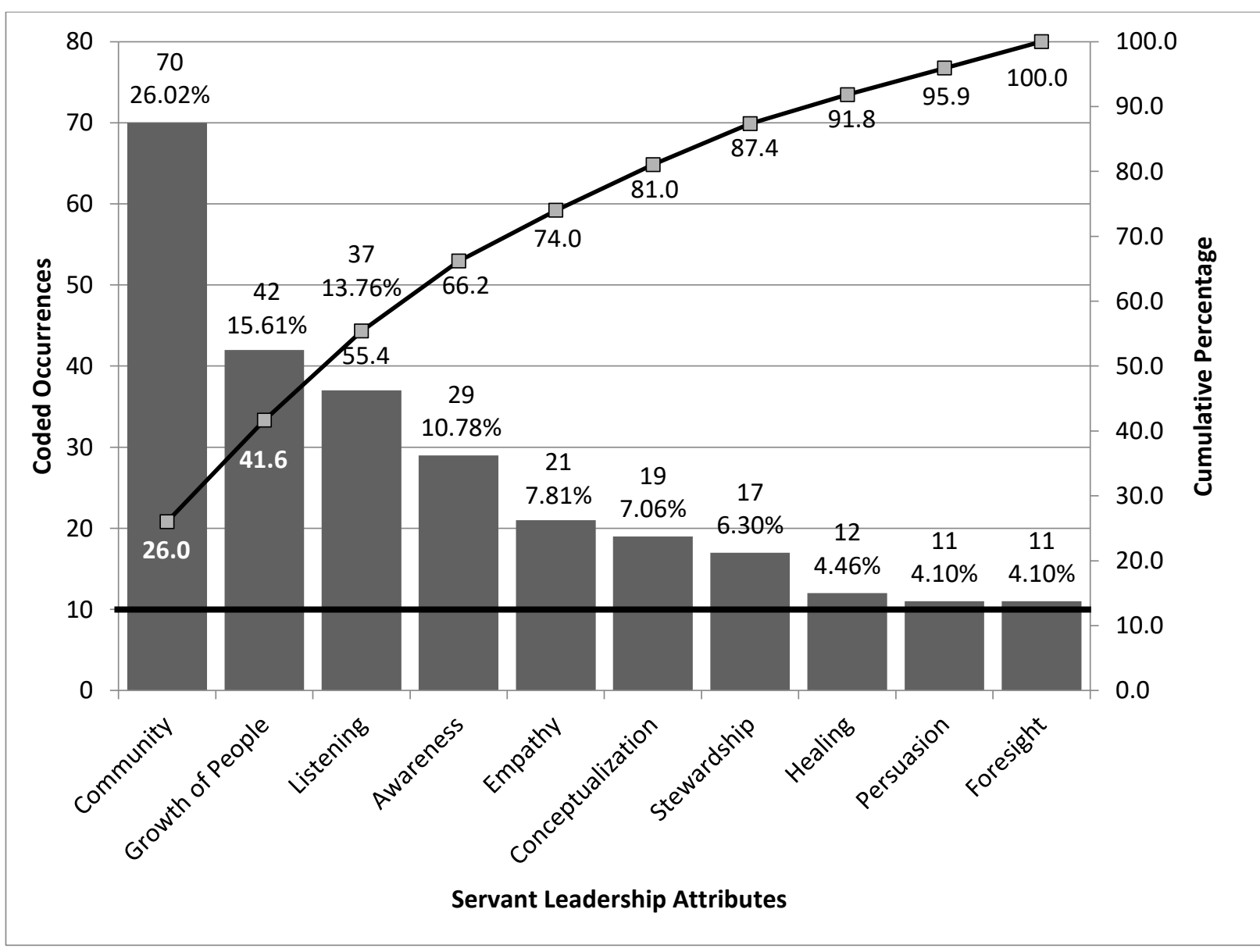

Following the same approach used to determine the nature and strength of association between the respondent described attributes and behaviors of Don, as themed into Spears' constructs of servant leadership, and their reporting relationship, we examined the same dependent variable, however, this time the independent variable was the types of https://ijbassnet.com/ business structures where Don and the respondents originally forged their relationships (nonprofit, private or nonprofit, private). Continuing to use the p-value approach, with an $\alpha=$ .10 (two-tailed) and $d f=9,(r-1)(c-1)$, it was concluded that there was, in fact, a statistically significant relationship, $\chi^{2}$ $(9, N=269)=14.86, p<.10$. As a result, we were able to 


\section{(C) Center for Promoting Education and Research (CPER) USA}

www.cpernet.org

conclude that there was a statistical association between the types of business structures where the respondents originally formed their relationships with Don and their perceptions of his attributes and behaviors as reflected in Spears' servant leadership constructs. For purposes of this analysis, the coded data from Don's interview was purposively excluded, since it would have distorted the findings. The $\varphi c=.2350$, which represented a moderately strong relationship between the variables.

\section{Discussion}

Our findings draw attention to previous research emphasizing the importance of executive characteristics to leadership behaviors (House et a., 1991; Peterson et al., 2012; Resick et al., 2009). Much of the leading research has focused on executive characteristics as determinants of transformational leadership. This isn't surprising since transformational leadership has been linked to important outcomes such as employee job satisfaction and organizational performance (Judge \& Piccolo, 2004). In this study, we responded to the growing concern that more research is necessary to support the theory and practice of servant leadership (Eva et al., 2019). Whereas some research has focused on servant leadership in healthcare, it has been largely focused on clinical positions. We intended to shed light on the actual attributes, behaviors, and antecedents of servant leadership by spotlighting a prominent healthcare leader with more than 65 years of career experience and a reputation for outwardly exhibiting the attributes and behaviors commonly associated with servant leaders.

In the process of uncovering the antecedents of servant leadership through our focus on Don, it was discovered that his family contributed early to the formulation of his values and work ethic and that these virtues laid a foundation for what would ultimately create a healthcare servant leader. In addition to the family, it was through a combination of his network of mentors, lived experiences, and personal and professional relationships that played an instrumental role in actually shaping his servant leadership attributes and behaviors. In a study that examined servant leadership antecedents associated with 12 leaders who had completed a community leadership program, Beck (2010) discovered that the longer a leader is in a leadership role, the more likely he or she will display behaviors commonly associated with servant leaders. This implies that servant leaders are constantly learning from their environment and using these lived experiences as a catalyst for the continuous shaping and refinement of their attributes and behaviors. Don was clear that he continued "growing" and learning throughout his career, which can be partially attributed to his constant exposure to different leadership styles and the relationships he cultivated and maintains to this day.

Another important antecedent that has contributed to his development into a servant leader stems from his spiritual beliefs and centeredness. Not only was this point emphasized, at various times throughout Don's interview, but it was reinforced in a number of the interviews with respondents who described, in a fair amount of detail, how they perceived that his spiritual beliefs influenced his attributes and behaviors. These findings are not inconsistent with other studies that have examined antecedents of servant leadership. Sendjaya and Sarros (2002) discovered that several servant leadership scholars have argued that spirituality provides a motivational basis for servant leaders and yet others have opined that spirituality enables a person to develop good moral habits (or virtues) which are appropriate in the workplace (Cavanagh and Bandsuch, 2002).

Don actively sought advancement throughout his healthcare career, but not as a means to gain influence and power for a selfish and self-serving reason, but rather as a springboard for change. He believes that leaders should serve the needs employees and that as a result, this would translate into improved job satisfaction (Drury, 2004; Mehta \& Pillay, 2011), retention of talent, enhanced organizational commitment (Drury, 2004; Liden et al., 2008; Rimes, 2011), better service to clients, and ultimately lead to the betterment of the community. In our interview with Don, he recounted an incident involving a young healthcare administrator, for whom he saw a great future within M. D. Anderson. Despite mentoring this young man, he eventually accepted an offer to join a competing organization for better compensation. $\mathrm{He}$ shared that this was "the first time that ever happened to me, and I was devastated. The idea of being attracted away for more money was something that was brand new to me." Later in the interview, he shared that he had purposively "passed off duties to him that was very significant" as a means of preparing him for future positions of greater responsibility within the organization. For the one-and-a-half interview, he came back to this particular incident four times. While he cognitively understood the employee's decision to accept a higher paying position, he believed his position gave him a unique position to help, in this case, an aspiring healthcare executive to move up the organization and that his commitment to the employee's future would be worth more than a salary increase. It is worth noting that this incident didn't deter him from continuing to use his position to aid employees, but was a reality check despite his best intentions sometimes other factors outside his control will intercede.

We predicted and affirmed that there was an association between the nature of the reporting relationship to Don and the respondents' collective perceptions of his attributes and behaviors as reflected in Spears' servant leadership constructs. Upon closer examination of the results, we could see that respondents who reported directly to Don were more likely to describe attributes and behaviors that would be more closely associated with someone who has regular, face-to-face interaction with a servant leader. For example, these respondents tended to emphasize behaviors that 


\section{CCenter for Promoting Education and Research (CPER) USA}

WWW.cpernet.org

related to listening and awareness and a lesser extent healing. These findings were not particularly surprising. After all, effective communication between managers and employees helps to establish trust not only in the manager but the upper echelon, which in turn fosters a commitment to the organization (Mishra et al., 2014). Employees appreciate it when leaders take a legitimate interest in them and make an honest effort to remain visible and approachable. Throughout his career, Don has always made a conscious effort to remain visible and interface with the staff in their work settings. One respondent commented that "...he [Don] would walk through the facility just to talk to people, to say hi and how's it going." His visible presence throughout the organization, approachability, awareness of the environment, and a sincere commitment to active listening were values aspects of his leadership style that resonated with his direct reports.

When it came to those respondents who didn't report to Don they tended to focus more on those attributes that would have a broader impact on the workforce and the organization's performance. They describe the attributes and behaviors associated with building a sense of community, stewardship, and to a lesser extent foresight. It is noteworthy to mention that a number of these respondents described him as being empathic towards the staff and even to the point of potentially compromising the operational performance of the business or at the risk of straining his professional relationships with other members of the senior leadership team. At various times in his career, he struggled to make difficult decisions that he knew would adversely affect employees and possibly their families. For instance, in the past, he has been unable to make mass layoff decisions without outside assistance. While he cognitively knew the layoffs were necessary, this didn't make the decisions any easier. To him, he felt partially at fault and knew how this would adversely impact the affected person and their families. There were times with Don probably spent more time working with certain employees than he should have and other times when he was perceived as not pushing employees hard enough. Many respondents were complimentary of his ability to pull people together into a unified team-based, in large part, on his legitimate concern for their well-being and his sincere commitment to their success. One respondent put it this way:

I think his [Don] success is probably due in large part that he's had people prop him up because they've wanted to do that, and rally around him, and be willing to go to the end of the earth with him. After all, they see how he treats people, and they too can become a success just by the way he treats them.

We discovered that there is, in fact, a relationship between the type of business structure nonprofit, private healthcare, or the public, nonprofit healthcare) where Don and the respondents originally formed their relationships and their collective perceptions of his leadership attributes and behaviors. The respondents in both settings were pretty close in terms of the frequency in which they described Don's attributes and behaviors. With that said, there were a few points of interest. First, the respondents that worked with Don in nonprofit, private healthcare entities tended to emphasize (or describe) behaviors associated with listening and awareness. This finding aligned with that observed in the respondents who directly reported to Don since a number of them also worked for him in a nonprofit, private healthcare organization. Conversely, there was an emphasis on foresight from the respondents who worked within nonprofit, public healthcare. This finding is not surprising since Don, as a general officer, would be expected to possess an intuitive understanding of the lessons from the past, the present realities, and the likely outcomes of a decision for the future (Parris \& Peachey, 2013).

In the spirit of honesty and transparency, the present study has a few limitations that should be noted when considering its findings and that can be addressed in future research. The data were collected from a series of semistructured interviews based largely on participant recollections that tend to become less clear over time. We don't believe this had a material impact on the study findings as to each participant, including Don, demonstrated an ability to recall details, which were often confirmed by secondary sources. While there is a growing body of research on the topic of servant leadership within the healthcare industry, this has been primarily focused on clinical personnel and settings. The lack of published research examining servant leadership within non-clinical ranks provided little in the way of foundations support for this study. That being said, it did create a gap in the existing literature for which we endeavored to address by focusing on a prominent non-clinical healthcare leader.

\section{Conclusions}

We have demonstrated that Don embodies the characteristics and attributes associated with a servant leader. As such, we used inductive reasoning to draw meaning from his personal and professional life and the perceptions from those who know him well and related our findings to servant leaders in similar roles within the industry. We realize that generalizing the findings from this study isn't possible; however, it does provide valuable insights into possible antecedents associated with the formation of servant leaders (i.e., relationships, spiritual centeredness, and desire for career advancement). The study also established that there is a statistical association between the reporting relationships and types of business structures (nonprofit, private and nonprofit, public healthcare organizations) to the types of attributes and behaviors associated with servant leaders. Not only is there an association, but the specific behaviors valued by these populations can and do differ in certain respects. More specifically, those who frequently interface with servant leaders are more likely to value those attributes and behaviors 


\section{(C) Center for Promoting Education and Research (CPER) USA}

www.cpernet.org

which personally impact them daily, such as listening, awareness, and healing. Conversely, those who do not have the same level of interaction with servant leaders seem to place greater emphasis on those attributes and behaviors which promote team unity and organizational commitment, such as building a sense of community and stewardship. These latter findings represent an original contribution to the existing body of work on servant leadership.

We believe that this study presents positive and practical implications for practice and research. In terms of practice, the healthcare industry needs to understand what makes servant leaders distinctive from other forms of leadership. This understanding should be drawn from the observations and perceptions of those who know servant leaders well, and not so much from a theoretical perspective. How a servant leader functions in the "real world" can be notably distinctive from data collected through the administration of an instrument where the measured items were based primarily on the review of literature versus actual servant leader behaviors. If utilized properly, servant leaders can strengthen inter-organizational and intro-organizational relationships; improve organizational outcomes through their genuine commitment to employee success; and focus employee and organizational efforts centered on supporting the holistic healthcare needs of the community. From a research perspective, these findings should be used as foundational support for future empirical studies geared towards assessing the presence and effectiveness of servant leaders holding key leadership positions within healthcare delivery systems. Given the scant amount of research looking at servant leadership within the healthcare and related sectors, we encourage scholars to more broadly focus research efforts on the application and effectiveness of servant leadership within these industries. Given the unique mission of healthcare, which is to serve the holistic healthcare needs of society, it would be logical to conclude that there is a legitimate role for servant leaders within this industry. In what capacity should servant leaders be considered is still an area of study which has been underrepresented in the literature. This study provided tangible examples of attributes and behaviors associated with one prominent servant leader. While Don is unique, in many respects, it's conceivable that other non-clinical, healthcare executives may share similar antecedents, behaviors, and attributes, and build like relationships with colleagues in differing business structures. More precisely, it allows researchers to develop measured items based, in part, on the realities of servant leaders' lives and not just rely on what is reflected in the literature.

\section{References}

Avolio, B. J. (2007). Promoting more integrative strategies for leadership theory0building. American Psychologist, 62, 25-33.

Beck, C. D. (2010). Antecedents of servant leadership: A mixed methods study. (Doctoral dissertation). Retrieved from: http://www.researchgate.net/researcher/81248916_Curtis_D_Beck

Bekker, C. J. (2010). Prophet and servant: Locating Robert Greenleaf's counter-spirituality of servant leadership. The Journal of Virtues and Leadership, 1(1), 3-14.

Biddix, J. P. (n.d.). Qualitative research design. Research Rundowns. Retrieved from http://researchrundowns.wordpress.com/qual/qualitative-research-design/

Cavanaugh, G. \& Bandsuch, M. (2002). Virtue as a benchmark for spirituality in business. Journal of Business Ethics, 38(1/2), 109-117.

DeRue, D. S., Nahrgang, J. D., Wellman, N., \& Humphreys, S. (2011). Trait and behavioral theories of leadership: An integration and meta-analytic test of their relative validity. Personnel Psychology, 64, 7-52.

Drury, S. (2004). Employee perceptions of servant leadership: Comparisons be level and with job satisfaction and organizational commitment (doctoral dissertation). Retrieved from

http://Olagroup.net/Images/mmDocument/Dury\%20Dissertation\%20Spring\%2004.pdf

Eva, N, Robin, M., Sendjaya, S., van Dierendonck, D., \& Linden, R. C. (2019). Servant leadership: A systematic review and call for future research. The Leadership Quarterly, 30, 111-132.

Graham, J. W. (1991). Servant-leadership in organizations: Inspirational and moral. Leadership Quarterly, 2(2), 105-119.

Greenleaf, R. (1977). Servant Leadership: A Journey into the Nature of Legitimate Power and Greatness. New York, NY: Paulist Press.

Greenleaf, R. (2003). The servant-leader within: A transformative path. NJ: Paulist Press.

Griffin, H. R. (2004). Analysis of servant leadership: An interpretive biography of a prominent healthcare leader. (Doctoral dissertation). Retrieved from ProQuest Digital Dissertations (AAT 3129595). 
House, R. J., Spangler, W. D., \& Woycke, J. (1991). Personality and charisma in the US presidency: A psychological theory of leader effectiveness. Administrative Science Quarterly, 36, 364-396.

Judge, T. A., \& Piccolo, R. F. (2004). Transformational and transactional leadership: A meta-analytic test of their relative validity. Journal of Applied Psychology, 89, 755-768.

Laub, J. A. (2003). From paternalism to the servant organization: Expanding the organizational leadership assessment (OLA) model. Retrieved from http://www.Regant.edu/acad/global/publications/sl_proceedings/home.cfm

Liden, R. C., Wayne, S. J., Zhao, H., \& Henderson, D. (2008). Servant leadership: Development of a multidimensional measure and multi-level assessment. Leadership Quarterly, 19(2), 161-177.

Mehta, S. \& Pillay, R. (2011). Revisiting servant leadership: An empirical study in Indian context. Contemporary Management Research, 5(2), 24-41.

Mishra, K., Boynton, L., \& Mishra, A. (2014). Driving employee engagement: The expanded role of internal communications. International Journal of Business Communication, 51(2), 183-202.

Parris, D. L. \& Peachey, J. W. (2013). A systematic literature review of servant leadership theory in organizational contexts. Journal of Business Ethics, 113(3), 377-393.

Peterson, S. J., Galvin, B. M., \& Lange, D. (2012). CEO servant leadership: Exploring executive characteristics and firm performance. Personnel Psychology, 65, 565-596.

Resick, C. J., Whitman, D. S., Weingarden, S. M. \& Hiller, N. J. (2009). The bright-side and dark-side of CEO personality: Examining core self-evaluations, narcissism, transformational leadership, and strategic influence. Journal of Applied Psychology, 94, 1365-1381.

Rimes, W. D. (2011). The relationship between servant leadership and organizational commitment (doctoral dissertation). Retrieved from: http://www.tntemple.edu/Application/files/Academics/DMin/W.\%20Rimes.pdf

Russell, R. F. (2001). The role of values in servant leadership. Leadership \& Organizational Development Journal, 22(1), 7684.

Sendjaya, S. \& Sarros, J. (2002). Servant leadership: It's origin, development, and application in organizations. Journal of Leadership and Organization Studies, 9(2), 57-64.

Sipe, J. W., \& Frick, D. M. (2009). Seven pillars of servant leadership: Practicing the wisdom of leading by serving. Mahwah, NJ: Paulist Press.

Spears, L. C. (1998). Tracing the growing impact of servant leadership. In L. C. Spear (Ed.), Insights on leadership: Service, stewardship, spirit, and servant-leadership (1-12). New York, NY: John Wiley.

Stone, G. A., Russell, R. F., \& Patterson, K. (2004). Transformational versus servant leadership: A difference in leader focus. Leadership \& Organization Development Journal, 25(3/4), 349-361.

van Dierendonck, D. (2011). Servant leadership: A review and synthesis. Journal of Management, 37(4), 1228-1261.

van Dierendonck, D. \& Patterson, K. (Eds.). (2010). Servant leadership: Developments in Theory and Research. Hampshire: Palgrave MacMillan.

Yin, R. (1994). Case study research: Design and methods. Thousand Oaks, CA: Sage. 